\title{
CORPOS DE TRABALHO, CORPOS DE FESTA: NEGROS E MESTIÇOS NA FESTA COLONIAL TRIUNFO EUCARÍSTICO, EM VILA RICA (1733)
}

BODIES OF WORK, BODIES OF PARTY: THE PARTICIPATION OF BLACKS AND MESTIZOS IN THE COLONIAL PARTY TRIUNFO EUCARÍSTICO, IN VILA RICA (1733)

CUERPOS DE TRABAJO, CUERPOS DE FIESTA: LA PARTICIPACIÓN DE NEGROS Y MESTIZOS EN LA FIESTA COLONIAL TRIUNFO EUCARÍSTICO, EN VILA RICA (1733)

\section{Mariana Soutto Mayor}

Mariana Soutto Mayor

Atriz, professora e pesquisadora de teatro

brasileiro. Atualmente é doutoranda no PPGAC/USP (bolsa Capes) e integrante do Lits, Laboratório de Investigação em Teatro e Sociedade da ECA/USP. 


\section{Resumo}

O trabalho tem por objetivo levantar questões para a análise das funções e formas da presença de homens e mulheres negras e mestiças nas festas coloniais do séc. XVIII em Minas Gerais, a partir do estudo de caso da festividade religiosa Triunfo Eucarístico, de 1733, em Vila Rica. O texto parte do estudo sobre a formação de artistas e artesãos negros e mestiços em Minas Gerais, e também da leitura de documentos e relatos de época, para investigar, do ponto de vista das artes cênicas, o papel dos artistas negros e mestiços nas práticas representacionais festivas que dominaram o cenário cultural da colônia desde o século XVI.

Palavras-chave: História do teatro negro, Performance negra, Festa colonial, Minas Gerais, Práticas representacionais do século XVIII no Brasil.

\section{Abstract}

This work aims to search questions for the analysis of the functions and forms of presence of men and women blacks and mestizas in the colonial parties of the $18^{\text {th }}$ century in Minas Gerais, from the study of case of the religious festivity Triunfo Eucarístico, in 1733, in Vila Rica. The text starts from the study about the formation of blacks and mestizos artists in Minas Gerais, and also from the lecture of documents and reportings of the time, to investigate, from the point of view of the studies of performance and theatre, the role of blacks and mestizos artists in the representational practices which dominated the cultural scenary of the colony since the $16^{\text {th }}$ century.

Keywords: History of black theatre, Black performance, Colonial festivity, Minas Gerais, Representational practices in 18th century in Brazil.

\section{Resumen}

Este trabajo tiene como objetivo alzar cuestiones para analizar las funciones y formas de la presencia de hombres y mujeres negras y mestizas en las fiestas coloniales de lo siglo 18 en Minas Gerais, a partir del estudio de caso de la fiesta religiosa Triunfo Eucarístico, en 1733, en Vila Rica, Brasil. El texto parte del estudio sobre la formación de artistas y artesanos negros y mestizos en Minas Gerais, y también de la lectura de documentos y relatos de época, para investigar, a partir del punto de vista de las artes escénicas, el papel de artistas negros y mestizos en las prácticas representacionales que dominaran el escenário cultural de la colonia desde el siglo 16.

Palabras clave: Historia del teatro negro, Performance negra, Fiesta colonial, Minas Gerais, Prácticas representacionales del siglo XVIII en Brasil. 
No mês de maio de 1733, as ruas de Vila Rica, Minas Gerais, foram tomadas por uma série de práticas culturais e religiosas em comemoração à trasladação do Santíssimo Sacramento da Igreja de N. Sra. do Rosário dos Pretos para a Matriz reformada de N. Sra. do Pilar. Toda a população da rica vila mineira, envolvendo pequenos comerciantes, lavradores, artistas, senhores de escravos, grandes mercadores, membros da burocracia local e representantes da Coroa portuguesa, assistiu e participou do chamado Triunfo Eucarístico.

A festa foi muito estudada do ponto de vista de sua riqueza, já que pode ser lida como uma forma de celebração e propagandística do sucesso da mineração em Minas Gerais. Porém, pouco se fala da importância da presença de mulheres e homens negros e mestiços ${ }^{1}$, escravizados e livres, maioria da população local, que atuaram ativamente tanto na organização como nas práticas artísticas apresentadas na festa.

Por meio de documentos da época, sabemos que esses homens e muIheres negras e mestiças atuaram na organização da festa pela Irmandade de

1. Utiliza-se aqui para denominar as populações de origem africana, afro-descendentes e mestiças no século XVIII em Minas Gerais os termos "negros" e "mestiços". O trabalho segue a análise crítica feita por Florestan Fernandes em $A$ integração do negro na sociedade de classes (1978) e O significado do protesto negro (1989), em que o professor assume a existência histórica de diferenças sociais entre negros e mestiços: "Como nós não temos um referencial claro, eu preferi usar as palavras negro e mulato. Se o preconceito no Brasil fosse mais definido e assumisse a forma que assume nos EUA e na África do Sul, o termo negro seria aceito por toda população negra e mestiça. O ideal de um movimento politico no Brasil é essa unificação, embora o mulato não esteja preparado para isso. Objetivamente porém, a participação do negro e do mulato na desigualdade é desigual. [...] Portanto, não posso dizer que o negro e o mulato vivem o mesmo drama, mas posso dizer que o mesmo drama cabe aos dois. Subjetivamente o mulato pode não absorver esse componente dramático em sua vida, mas objetivamente ele leva vantagem em relação ao negro, isto ele leva. Se eu pegar algumas estatísticas poderemos ver, por exemplo, no que se refere às oportunidades educacionais, no nível dos diplomados, fica patente um nível de competição mais definido. Vê-se que, quando se passa do ensino primário ao nível médio, as diferenças entre negros ao superior. Ou seja, as oportunidades são distribuídas desigualmente, favorecendo mais o mulato e dando-lhes meios de competição e de ascensão que o grosso da população negra não possui." (FERNANDES, 1969, p. 68-69). Em geral, nos documentos históricos de Minas Gerais do século XVIII há a utilização dos termos "negros", "pardos" e "mulatos". As próprias irmandades se dividiam entre "irmandades de pretos" e "irmandades de pardos", marcando as diferenças que existiam por conta da relativa ascensão social em função do tom da pele do indivíduo. Historicamente, sempre houve no Brasil uma hierarquia relativa aos tons de pele. Assume-se neste trabalho essa diferença com as expressões "negros" e "mestiços". Atualmente, os termos "pardo" e "mulato" estão sendo revistos historicamente por movimentos sociais por seu sentido pejorativo. Alguns dos trabalhos aqui citados, por uma questão histórica, como o do próprio Florestan, utilizam a expressão "mulato". Reproduzimos os trechos originais, com as palavras escritas pelos autores. 
N. Sra. do Rosário dos Pretos. Além disso, eles estavam presentes em procissões e apresentações do Triunfo Eucarístico como músicos, dançarinos, atores, assim como, por meio da figura do pajem, também estavam nos desfiles processionais, que "cobertos de ouro", acompanhavam as figuras alegóricas e os carros triunfais.

As fontes documentais que chegaram até nós são exemplos dos limites de nossa historiografia do teatro negro no Brasil, pois só nos restaram registros feitos pela perspectiva das elites locais, que dominaram a produção e circulação de textos sobre os acontecimentos na Colônia, seja na forma de relatos, cartas, documentos burocráticos da câmara ou da Coroa portuguesa. Nosso esforço ao estudar a história do teatro negro e mestiço é justamente ter que lidar com documentos que oferecem perspectiva histórica. Para irmos além da história oficial, é preciso imaginar outros lados, infelizmente a partir de registros das classes dominantes.

Este trabalho procura levantar elementos para o estudo da presença dos chamados "desclassificados do ouro"2 na celebração do Triunfo Eucarístico, do ponto de vista das artes cênicas nas festas coloniais, que dominaram o cenário cultural do Brasil colônia dos séculos XVI, XVII e XVIII.

Para além de negros e mestiços serem a maioria da população local ${ }^{3}$, o principal fator que organizou sua participação na festividade foi a existência das irmandades religiosas negras e "pardas" em Minas Gerais. $\mathrm{O}$ objetivo inicial das irmandades, num cenário dominado pelo catolicismo, foi estimular uma vida devota e educação religiosa. Contudo, pelas escassas condições materiais da população em geral, isto é, de negros e brancos, as funções religiosas se misturaram com funções sociais. As irmandades leigas eram os principais espaços de sociabilidade numa cidade carente de tradições e

2. A expressão "desclassificados do ouro" faz menção ao importante estudo da historiadora Laura de Mello e Souza sobre a pobreza e miséria em Minas Gerais do século XVIII por meio da análise de documentos sobre homens livres pobres, negros e mestiços escravizados e forros que estavam à margem da principal atividade econômica da região, a mineração: "A gente livre pobre que descambou com frequência para a desclassificação social foi, pois, no século XVIII, predominantemente negra e mestiça, bastarda e oriunda de casas dirigidas por mulheres sozinhas. Franja da sociedade organizada, apresentava uma mescla curiosa de crime e trabalho, liberdade e cativeiro, norma e infração" (SOUZA, 1986, p. 144).

3. Em 1776, a tabela de população referente acusava a existência de "70.769 brancos, 82.000 pardos e 167.000 pretos, num total de 319.769 indivíduos" (REVISTA DO ARQUIVO PÚBLICO MINEIRO, 1899, p. 294). 
memórias locais. ${ }^{4}$ Se por um lado a população organizada em irmandades construía templos e fazia cultos, também fazia assistência mútua para a preparação de uma boa morte, funerais, missas e sepulturas.

No caso das irmandades negras, vínculos e sociabilidade eram mais fortes, dada à condição ainda mais precária de parte de seus membros: muitos deles eram escravizados. Esses homens e mulheres viviam na tensão entre obediência ao Estado e à Igreja e a resistência social - fato que tornava as irmandades negras espaços de contradições permanentes. Ao mesmo tempo respeitavam as ordenações religiosas para a organização de irmandades, submetiam-se à paróquia de sua região e acatavam uma hierarquia de importância de irmandades, em que sempre irmandades de pardos e negros ficavam em segundo plano; contudo, também realizavam congadas e coroamentos de reis e rainhas negras, compravam alforria de escravos e utilizavam o espaço das irmandades para a realização de cultos africanos. ${ }^{5}$

Devido à sua importância na vida social de Vila Rica, em grande parte foram as irmandades que estimularam a produção artística local pela encomenda de construções de igrejas, retábulos, altares, quadros, procissões, músicas etc. Assim, foi necessária a contratação de artistas especializados para essas execuções. O caso de N. Sra. do Rosário dos Pretos é exemplar na cidade, pois

4. De acordo com a historiadora Laura de Mello e Souza, a carência de tradições e memórias locais naquela região gerou a possibilidade de inventar normas diferentes das portuguesas: negros e mestiços puderam, assim, integrar instituições que a priori restringiam seu acesso, como câmaras, irmandades religiosas e santas casas de misericórdia. Em comentário na biografia de Cláudio Manuel da Costa, escreve: "Desde os primeiros tempos do povoamento, construíra-se em Minas Gerais uma cultura política específica, marcada pelo conflito e pela irreverência. O território vasto e acidentado, a composição complexa da sociedade só agravava as coisas: muito negro, escravo e livre; muito índio bravo, muito arrivista sem escrúpulo, tradições tênues e ainda por cima sedimentar, muita riqueza convivendo com a pobreza mais abjeta. Em 1720, houvera um levante de poderosos contra o estabelecimento das casas de fundição, e um pequeno comerciante, Filipe dos Santos, acabara morto e esquartejado sem julgamento, fazendo com que o governador, Conde de Assumar, fosse seriamente repreendido. Em meados da década de 1730, quando se procurou, mais uma vez, mudar o sistema de tributação, uma série de motins sacudiu os sertões do médio rio São Francisco, ameaçando o controle português sobre a região. Isso sem falar da centena de quilombos espalhados pela capitania e dos boatos recorrentes de que um levante escravo ia pôr a perder o controle dos poucos brancos sobre a multidão dos negros e mestiços despossuídos" (SOUZA, 2011, p. 172).

5. Muitos pesquisadores se debruçaram no tema das irmandades negras em Minas Gerais do século XVIII, com diferentes perspectivas. Em especial, os historiadores Julita Scarano, Caio Boschi, Marcos Magalhães de Aguiar, Celia Maia Borges, Lucilene Reginaldo, assim como o poeta Carlos Drummond de Andrade na crônica "Rosário dos homens pretos", presente no livro Passeios na ilha, de 1952. 
no Triunfo Eucarístico foi a irmandade que financiou a publicação do panegírico festivo escrito por Simão Ferreira Machado (1967b) e publicado em Lisboa em 1734, além de participar dos desfiles processionais e organizar a festa em conjunto com a irmandade do Santíssimo Sacramento e a Câmara Municipal.

Em decorrência dessa própria demanda interna, é possível afirmar que as irmandades eram não apenas espaços de promoção artística, mas também de formação artística de alguns de seus membros. Era comum a presença de artistas entre os membros das irmandades. ${ }^{6}$

Entretanto, para se analisar a grande quantidade de artistas negros e mestiços em Vila Rica que participaram da realização da festividade mineira, é preciso ir além do espaço das irmandades e considerar o fenômeno social da absorção dessa população pelas casas de artes e ofícios na segunda metade do século XVIII, na capitania de Minas Gerais. Segundo o pesquisador Jaelson Trindade:

A participação do mulato nas artes e ofícios foi maior nos centros de grande escravaria, de vida comercial mais pujante, como Recife, Salvador, Rio de Janeiro e Ouro Preto. Nesse contexto, a antiga Capitania das Minas Gerais foi que acolheu o maior número de mulatos artífices entre os trabalhadores urbanos da época colonial brasileira. Uma porção deles alforriados ou livres de nascimento. Essa concentração tem uma data: a $2^{-}$metade do século XVIII. E corresponde a uma outra concentração, nunca antes vista na Colônia: uma rede volumosa e homogênea formada por núcleos como São João Del Rei, São José do Rio das Mortes (Tiradentes), Ouro Preto, Mariana, Sabará, Serro, Tijuco (Diamantina) e muitas outras vilas e arraiais. [...] A intensa atividade dos pardos na Ouro Preto oitocentista fez com que eles pudessem formar orquestras, grupos bem estruturados, passando a atender o Teatro da Ópera local, além das solenidades realizadas pelo Senado da Câmara. (TRINDADE, 1988, p. 121-129)

O fenômeno destacado por Trindade (1988) só foi possível pela extensa população de negros e mestiços em Vila Rica, que acabou ocupando espaços sociais antes destinados somente a brancos, como no caso de corporações

6. Podemos pensar no caso de Francisco Xavier de Brito e Manoel de Brito, ambos portugueses que vieram para Minas Gerais logo no início de sua formação. Os dois trabalharam na Ordem Terceira da Penitência no Rio de Janeiro e participaram em Ouro Preto na construção da Matriz do Pilar. Curiosamente, Francisco Xavier de Brito pertencia à Irmandade de São Miguel da Matriz do Pilar de Ouro Preto. (CAMPOS, 2006, p. 52). 
de ofícios. ${ }^{7}$ Não que esses homens brancos fossem ricos ou tivessem prestígio social, pois sabe-se que ofícios mecânicos, seja de artesão, mestre de obras, musicista, arquiteto, pintor ou ator, por exemplo, eram desprezados pela elite colonial e todo o trabalho manual era ocupado por homens livres ou destinado aos próprios escravizados.

É possível pensar na tese defendida por Trindade (1988) de que entre os artistas que trabalharam em Minas Gerais, predominaram os emigrados portugueses até a década de 1770, que começaram a ser substituídos na década seguinte por oficiais mestiços em virtude da ausência de estatuto corporativo que defendesse privilégios e posições de brancos no mercado. Ao mesmo tempo, é preciso considerar que, para além da ausência dos estatutos corporativos, há um aumento populacional de negros e mestiços, em proporção ao de brancos, que limita numericamente a própria atuação de brancos nas corporações (TRINDADE, 1988, p. 128).

Nesse processo histórico, negros e principalmente mestiços ocuparam cargos nas artes e ofícios de Vila Rica, dentro de determinada divisão social e técnica do trabalho. Geralmente, negros escravizados trabalhavam como aprendizes de brancos e mestiços livres ou forros, respeitando uma hierarquia que respondia a condições materiais e econômicas, mas também ao tom da pele.

São notáveis as diferenças existentes entre negros e mestiços dentro de uma mesma corporação ou irmandade, refletindo um aspecto daquela sociedade de que mestiços tinham acesso a cargos mais altos de trabalho - mas nunca ultrapassando os lugares de brancos. ${ }^{8}$

7. Complementando a afirmação, Charles Boxer escreve: "O fato de a maioria dos homens brancos ter filhos mulatos, legítimos ou não, constituiu-se um problema social e administrativo para gerações em sucessão. Pela lei, sangue negro era um obstáculo para ocupar qualquer cargo cívico ou oficial, tal como uma cadeira na Câmara Municipal, mas essa barreira de cor era frequentemente transposta. [...] Contanto que o habitante não fosse escuro demais, era antes a riqueza e não a cor a permanecer como critério principal, no que se referia aos cargos municipais em Minas Gerais, conforme Gomes Freire de Andrade notou muitos anos depois. Além desses homens de cor que se conseguiram fazer passar por brancos, houve, no decorrer do tempo, muitos outros que se tornaram pessoas de fortuna $e$ bens, exercendo profissões tais como pintura, música e direito" (BOXER, 2000, p. 192).

8. O padre André Antonil, no início do século XVIII, citaria o provérbio já conhecido na Colônia daquele período de que o Brasil é "purgatório dos brancos, inferno dos pretos e paraíso dos mulatos e das mulatas", marcando a diferença existente entre tons de pele e organização social desde o Brasil colônia (ANTONIL, 1982, p. 36). 
Esse universo do trabalho artesanal e artístico se aplica às corporações de ofício, porém se relaciona diretamente com as próprias irmandades, criando um mercado interno e relações não só econômicas, mas artísticas e sociais. As corporações dependiam das irmandades e vice-versa.

Seja como artistas das irmandades, seja como membros das corporações de ofício, quando olhamos para alguns estudos sobre o teatro na Colônia ou sobre a história da música no Brasil, vemos a preponderância da participação de mestiços nos dois casos, profissionalizando-se como artistas. Nas práticas cênicas coloniais, os grupos profissionais se organizavam de acordo com o tom de pele e a condição dos integrantes serem escravizados ou não. Um grupo poderia ser de "pardos", "crioulos" ou "negros", ou ainda de "curiosos" - estes geralmente formados por brancos da elite local que se aventuravam no teatro, formando grupos amadores especialmente para as apresentações. De acordo com a pesquisadora Rosana Brescia:

Com relação aos actores e demais artistas que formavam os elencos dos teatros realizados em palcos efémeros durante as festas públicas, concluímos que, dentro de uma mesma festa, as distintas representações dramáticas poderiam ser realizadas por companhias diferentes, incluindo profissionais -geralmente músicos e actores pardos já com alguma experiência na arte dramática e contratados pelo sistema de arrematações-, "crioulos" ou escravos forros pagos pelas representações, estudantes ou homens "principais da cidade" denominados "curiosos", que subiam à cena em honra do Rei ou de uma autoridade colonial em sinal de gratidão e dedicação. De modo geral, as companhias não se misturavam, obedecendo a devida hierarquia com respeito à classe social e ao grau de limpeza de sangue de seus componentes; muito embora as companhias de origens diferentes pudessem integrar o programa de uma mesma festividade, na qual distintas óperas e comédias eram atribuídas a distintos grupos de actores, que representavam para um mesmo público em comemoração de uma mesma efeméride. (BRESCIA, 2000, § 35)

No caso das atividades musicais, como também nas artes plásticas e arquitetônicas, havia a predominância de mestiços, como afirma Curt Lange:

O mulato em Minas Gerais foi o verdadeiro orientador de toda atividade artística e quase seu único intérprete. Essa circunstância deve ter sido aceita como natural e não como irremediável. Em todo caso, foi um fato consumado. [...] Um minucioso estudo dos livros das irmandades 
conduz-nos imediatamente à descoberta do "mulatismo musical", se assim podemos chamá-lo. Os homens de cor se haviam agrupado - referimo-nos a Vila Rica, onde se conservou maior número de documentação - nas Confrarias da Boa Morte, das Mercês dos Perdões, das Mercês de Cima, de São José, de São Francisco de Paula, porém seu campo de ação não era somente o da sua própria igreja e freguesia, já que a antiga Vila Rica estava dividida em duas: N. Sra. do Pilar de Ouro Preto e N. Sra. da Conceição de Antonio Dias. Nossos músicos circulavam livremente e se apresentavam também nos templos cujas irmandades e ordens terceiras só admitiam brancos. (LANGE, 1982, p. 129) ${ }^{9}$

A participação intensa de homens e mulheres mestiças e negras nas atividades artísticas de Vila Rica não significava o fim de hierarquias sociais, privilégios e preconceitos. Esse fenômeno social era tolerado pela igreja e autoridades locais pelas circunstâncias históricas, mas não aceito totalmente. A sociedade de Vila Rica no século XVIII continuava mantendo uma rígida hierarquia social, sua estrutura escravocrata e os privilégios dos homens brancos, em especial da elite branca local.

\section{Homens e mulheres negras e mestiças na festa do Triunfo Eucarístico}

Se observamos o relato de Simão Ferreira Machado (1967b) sobre a festa - o principal documento histórico sobre a festa do Triunfo Eucarístico

9. O pesquisador Jaelson Trindade complementa a afirmação de Lange: "O mulato, livre ou forro, encaminhou-se em maior número para o aprendizado da música. Nos regimentos de linha e nas tropas auxiliares das milícias coloniais, os pardos ocupam as funções de timbaleiros e mestres da música; de trombeteiros, tocadores de tambor e pífano. E se metem também no coro das igrejas, nos cortejos cívicos e religiosos, nos tablados de teatro, com suas violas, violinos, oboés, flautas, charamelas, atabales, timbales, rabequinhas e zabumbas. [...] No Recife, no Rio de Janeiro e especialmente em Minas Gerais foi bastante grande essa atuação do mulato. Em Ouro Preto, há inúmeros "professores de música", alguns deles autores de notáveis composições que os musicólogos vêm resgatando e divulgando: Francisco Gomes da Rocha, José Emérico Lobo de Mesquita, Inácio Parreira Neves e Marcos Coelho Neto, são os mais conhecidos. Há também um José Maurício Nunes Lisboa, cujo nome faz lembrar que é de origem mineira o famoso Padre José Maurício Nunes Garcia, outro mulato, que se destacou na Corte do Rio de Janeiro. Todos aqueles músicos pertenciam a outras irmandades de pretos - Rosário e Sta. Ifigênia - não se encontra, segundo Curt Lange, "o nome de músicos proeminentes, mas nelas aparecem os tocadores de instrumentos de percussão, os buzineiros, os charameleiros, os trombeteiros e gaiteiros [...] Uma categoria diferente de pretos e mulatos escravos foi educada musicalmente pelos músicos proprietários deles, que os alugavam para tocar na cabeça das procissões e anunciar, ao amanhecer, o dia da festividade religiosa" (TRINDADE, 1988, p. 129). 
que chegou às nossas mãos -, podemos ter algumas pistas sobre como foi organizada socialmente a celebração colonial e, assim, estudar sobre a presença de artistas negros e mestiços no acontecimento festivo.

No que toca às artes plásticas, a celebração, que durou aproximadamente um mês, foi estruturada por meio da modificação do espaço público de Vila Rica, onde as janelas das casas foram adornadas com tecidos e tapeçarias, foram criadas decorações efêmeras e toda a vila iluminada. Em pontos importantes do trajeto foram edificados arcos triunfais, provavelmente seguindo as características da arte barroca colonial. Como arquitetura efêmera, é provável que fossem arcos provisórios de madeira ou cera, construídos por artistas da cidade, contratados pelas irmandades das corporações de ofício de Vila Rica. O Triunfo Eucarístico certamente foi elemento importante na instauração do imaginário do chamado "barroco colonial" em Vila Rica.

A temporalidade da festa foi também preparada pela anunciação prévia: por alguns dias houve mascarados que, entre trajes cômicos e graciosos, saíram pelas ruas para anunciar o cortejo. Os mascarados que saíram pelas ruas anunciando a festividade por vir são descritos de maneira simples por Machado:

Deu princípio aos festivos dias um bando por ministério de vários mascaras; uns aprazível objecto da vista nas diferenças do traje, e precioso da compostura; outros na galantaria das figuras assunto de riso, e jocosidade: todos por diferentes modos anunciaraõ ao povo a futura solenidade, desde os fins de Abril até três de Mayo. (MACHADO, 1967b, p. 193-194)

É provável que os mascarados cômicos do Triunfo Eucarístico tivessem saído pelas ruas da cidade fazendo brincadeiras e gestos grotescos. $O$ cotidiano de trabalho da população certamente se modificou com essas figuras que falavam alto pelas ruas, cantavam e possivelmente até tocavam instrumentos. Não poderemos saber até onde ia a ousadia dos mascarados cômicos do Triunfo Eucarístico, mas começamos a ter uma ideia de como eles interviram cenicamente pela cidade. Ainda mais no caso de artistas mestiços ou negros, pois é muito provável que houvessem brincadeiras sobre as relações sociais e raciais em Vila Rica, tanto por parte dos artistas quanto por habitantes da cidade.

No dia da trasladação do Santíssimo Sacramento, houve cortejo religioso com danças, músicas, alegorias, carros triunfais, irmandades, autoridades 
religiosas e políticas que saíram da Capela de N. Sra. do Rosário em direção à nova Matriz do Pilar de Ouro Preto.

A partir do estudo do relato escrito por Machado (1967b, p. 201), podemos destacar algumas funções ocupadas por negros e mestiços. A primeira delas seria a de músicos: "Vinhaõ apé oito negros, vestidos por galante estilo, tocavaõ todos charamellas, com tal ordem, que alternaõ as suas vozes com as vozes do clarim, suspendidas humas, em quanto soavaõ outras".

Por essa descrição, podemos imaginar que não se tratavam de músicos amadores, no caso dos músicos negros, além de tocarem instrumentos, como o clarim e a charamella ${ }^{10}$, faziam um arranjo vocal em coro com variações. Esses músicos são citados em outro momento da procissão, acompanhando figuras alegóricas:

Mais distancia de dous passos vinhaõ quatro negros cobertos de chapeos agaloados de prata com plumas brancas; vinhaõ em cavalos brancos de jaezes de berne tocando trombetas, de que pendiaõ estandartes de seda branca com huma custodia de prata (MACHADO, 1967b, p. 251-252).

Em trajes finos, esses músicos negros seguiam a lógica de fausto e ostentação da festa, suspendendo o cotidiano de Vila Rica, onde negros escravizados nem sequer usavam sapatos. A descrição constante de Machado sobre as pedras e metais preciosos, tecidos expostos na festa por figuras alegóricas, músicos, carros triunfais e pelos próprios negros escravizados, revelam a cultura do ouro na qual estava mergulhada Vila Rica. Porém, as diferenças sociais e raciais estão marcadas. $O$ tom do texto de Machado nos dá pistas sobre essas questões:

Vinhaõ ás estribeiras seis pajens; três a cada lado; mulatinhos de gentil disposição; todos da mesma estatura e semelhantes no traje. [...] Precedia a todas (as irmandades) um gaiteiro, que por singular fabrica do instrumento e boa agilidade da arte fazia uma agradável consonância. Vestia á Castelhana de seda encarnada; e por um lado o seguia um moleque vestido da mesma seda tocando um tambor. (MACHADO, 1967b, p. 206-207)

10. Segundo Afonso Avilla (1967a, p. 288), charamella é "antigo instrumento, com uma palheta metida em cápsula ou barrilete, onde se soprava com força, como nas buzinas, e que se pode considerar precursor do oboé ou clarinete." 
Chama atenção nesse trecho o termo "mulatinhos", como forma de falar dos seis pajens que seguiam uma figura alegórica. Há duas possibilidades de interpretação desse termo: pode-se pensar o uso do diminutivo como forma de o autor destacar o fato de serem crianças mestiças; como também é possível pensá-lo com uma carga pejorativa e racista, em que está implícito um juízo de valor, já que a presença de músicos e artistas negros e mestiços na procissão era tolerada, mas não valorizada pelos membros da elite branca letrada.

Segundo a historiadora Silvia Hunold Lara, as danças e manifestações apresentadas nas procissões das festas coloniais por negros, mestiços ou índios tinham um sentido de enaltecer as glórias do Império português, marcando a dominação e a conquista sobre esses povos:

Com os integrantes dispostos em longas e numerosas procissões que desfilavam diante de palanques e camarotes especialmente construídos para a ocasião, tais danças de índios, caboclos ou pretos revestiam-se de um sentido diretamente relacionado às glórias do Império português. Assim como as alegorias dos continentes combinavam com as representações das virtudes da nobreza de sentimentos ou de máximas morais, elas traziam para o contexto laudatório da monarquia um exemplo das gentes da conquista e seus costumes. (LARA, 2007, p. 187)

No caso do Triunfo Eucarístico, de acordo com o relato de Machado, não houve a apresentação de nenhuma dança africana ou indígena, como no caso de outras festividade; porém, podemos imaginar o contraste que era a presença de artistas negros e mestiços numa festa organizada para a exaltação da cultura cristã e de modelos europeus, marcando as forças sociais em tensão. No relato de outra festa colonial mineira que ocorreu pouco tempo depois do Triunfo Eucarístico em 1748, em Mariana, intitulada Aureo Throno Episcopal, há a seguinte descrição, que revela bem as tensões sociais em jogo:

Seguia-se às sobreditas figuras huma dança de Carijós, ou gentio da terra. Era esta ajustada de onze mulatinhos de idade juvenil, nus da cintura para sima, a qual cingião varias plumas cinzentas cahidas atè os joelhos, formando saiote: rodeavão as cabeças penachos das mesmas plumas, e outros fingidos de papel pintado, e latas crespas; nos braços, e pernas tinhão varias prisões de fitas, maravalhas, e guizos; na variedade das mudanças ufavão de huns arcos, com que formavão diversos enleios, cantando ao mesmo tempo celebres toadas ao som do tamboril, flautas, e pífaros pastoris, tocados por 
outros Carijós mais adultos, que na grosseria natural dos gestos excitavão motivo de grande jocosidade. (AVILA, 1967a, p. 454-455)

O comentário final escrito no relato, com uma adjetivação pejorativa ao modo de dançar dos "mulatinhos" a dança indígena dos Carijós, confirma o juízo de valor preconceituoso, marcando a dança em questão como algo pitoresco, grotesco, bizarro. A apresentação de uma expressão artística genuína dos povos originários do Brasil na festividade religiosa serve mais como legitimadora da dominação colonial do que como possibilidade de integração social. A pesquisadora Marianna Monteiro analisa esse aspecto das festas coloniais do ponto de vista da dança:

Todavia, não estamos na corte. No Balé Ambulatório, o que se organiza para a dança é toda uma vila. Os lacaios do palácio são os "escravos da guiné". [...] No lugar dos "nostálgicos" nobres da pastoral cortesã europeia, são os mestiços, os negros e os índios os personagens desse teatro da religião, que é também teatro da opressão, da guerra contra o infiel e do martírio cristão. [...] No cortejo colonial, a presença do escravo, do índio, do mulato e do negro fazia da procissão um momento da administração efetiva de forças sociais em tensão. Com a participação efetiva das irmandades, da câmara e das corporações de ofício e milícias, modificava-se em profundidade o sentido da festa barroca no Brasil que passava a ser concretização no plano espetacular e simbólico da missão atribuída a Portugal por Deus. (MONTEIRO, 2001, p. 821)

No palco do tablado de madeira erigido especialmente para as apresentações de peças do Século de Ouro espanhol nas noites seguidas à procissão, é provável que os atores fossem esses mesmos artistas negros e mestiços, participantes de grupos profissionais, que interpretavam nobres, príncipes, viIões e mocinhas espanholas nas peças El secreto a voces, de Calderón de la Barca, El príncipe prodigioso, de Don Juan de Matos Fragoso e Don Agustín Moreto, e Donde hay agravios hay zelos, y amo criado, de Francisco Rojas. Esses atores negros e mestiços interpretavam o texto retórico em castelhano, de elogios à honra e ao amor. O cotidiano de barbárie escravista vivido pelos atores era por algumas horas sublimado pelas falas em versos e brigas de cavalheiros, deixando escapar que talvez as ideias estivessem fora do lugar. ${ }^{11}$

11. Aqui há a referência ao texto de As ideias fora do lugar, do crítico Roberto Schwarz. 
Pode-se observar que na festa também havia as figuras de pajens acompanhando alegorias e irmandades. Esses pajens, sendo negros, mestiços ou até mesmo brancos, estavam em uma relação de servidão. Não há dados para saber quais grupos sociais da população de Vila Rica representavam essas figuras, entretanto, elas deveriam corresponder a funções servis daquela sociedade. Tudo na festa espelhava a sociedade de Vila Rica, a condição de uma Colônia imersa em ouro e ao mesmo tempo na escravidão, ora de forma refletida, ora refratada, ora distorcida:

Pelos lados a seguiaõ apé dous pajens, como pinta a antiguidade a Mercurio: nas cabeças davaõ nos chapeos ao vento duas azas: vestiaõ justilhos brancos de Olanda, do que sahiaõ nas costas duas azas: cingiaõ três fraldins de seda encarnada com flores de varias cores: calçavaõ de branco com servilha de talhares: nas mãos os caducos columbrinos. (AVILA, 1967a, p. 211-212)

Ao olhar para relatos de outras festividades coloniais, percebe-se que homens negros e mestiços também estavam em relação servil ao assumir a função de figuras de apoio na procissão para o bom funcionamento dos carros triunfais. Esses homens poderiam atuar inclusive como cocheiros, montados a cavalo. Na festa recifense, de 1745, em comemoração a São Gonçalo Garcia, há duas descrições no relato de época que nos ajudam a imaginar as funções exercidas por eles:

Tiravão do sobredito carro quatro homens pretos com aceyo vestidos. Cobrião-Ihes as cabeças trumphas á mourisca com laços de fitas, e pontas perdidas na parte posterior. Cobria este carro a Irmandade do Santíssimo da freguesia, em número mais de quarenta. (RIBEIRO, 1926, p. 33)

E ainda:

Tiravão a esta portentoza machina dous cavalos ruços pombos cobertos de mantas de tafetá [...] Guiavão a estes dous homens pretos ornados á trágica: cobrião-lhes as cabeças dourados capacetes com plumas, e cocares brancos, que rematavão laços de fitas: vestião camizas crespas: pendião-lhes dos hombros laços de fitas, e bolotas de ouro. (Ibid., p. 38)

Num dos momentos de maior destaque da procissão do Triunfo Eucarístico, na saída das irmandades locais, negros e mestiços estavam 
presentes representando suas próprias irmandades. Apesar de serem descritos com ênfase nas roupas e adereços finos, havia uma rígida hierarquia entre as irmandades, colocando em destaque as confrarias dos brancos ricos, que eram as últimas a integrar o desfile. A Irmandade de N. Sra. do Rosário dos Pretos, embora tenha participado da organização da festividade e financiado a publicação do relato da festa, era a segunda a desfilar - o que do ponto de vista da hierarquia das irmandades, era ser considerada "menos importante" que as outras:

Seguia-se a irmandade da Senhora do Rosário dos pretos, numerosa de muitos irmaõs, todos com opas de seda branca. No meyo dela hiaõ três andores: o primeiro de Santo Antonio Calatagirona: o segundo de S. Benedito: o terceiro da Senhora do Rosario: nas imagens era muito vistoso o ornato em sedas de ouro, e diamantes: nos andores em sedas, galoens, e franjas de ouro; e variedade, e galantaria de diferentes flores de diversas matérias, e alternadas cores. (RIBEIRO, 1926, p. 253-254)

Tudo na festa parecia remeter às relações sociais e raciais em Vila Rica, apesar de a suspensão do cotidiano da vila e dos esforços em enfeitar qualquer elemento e qualquer participante - inclusive os cavalos - com pedras e metais precisos. Os protagonistas da festa são quem dita as regras daquela sociedade, que ocupa os lugares privilegiados em desfiles, camarotes, banquetes, arquibancadas e igrejas. Aos negros e mestiços, escravos, artesãos e artistas daquele local, restava cumprir seus trabalhos em figurinos de ouro, na contradição de que nem no momento festivo podiam se esquecer de suas condições sociais e raciais. A perspectiva desses homens e mulheres ainda está para ser contada em nossa história do teatro.

A festa como fenômeno cultural e social confirma historicamente, apesar dos disfarces das pedras e metais preciosos, que a particularidade da Colônia foi a escravidão negra e indígena. Esse fato bárbaro, presente em todos os processos políticos e econômicos da nossa história, também aparece refletido e mediado em nossas práticas culturais. ${ }^{12}$

12. Para melhor compreensão do assunto, recomenda-se a leitura de alguns autores, como Caio Prado Jr., Jacob Gorender, Fernando A. Novais, Decio Saes e Luiz Felipe de Alencastro. 


\section{Referências bibliográficas}

ANTONIL, A. J. Cultura e opulência do Brasil. 3. ed. Belo Horizonte: Itatiaia, 1982. AVILA, A. Resíduos Seiscentistas de Minas Gerais: textos do século do ouro e as projeções do mundo barroco. v. I. Belo Horizonte: Universidade Federal de Minas Gerais, 1967a.

Resíduos Seiscentistas de Minas Gerais. v. II. Belo Horizonte: Universidade Federal de Minas Gerais, 1967b.

BOXER, C. R. A idade do ouro no Brasil: dores de crescimento de uma sociedade colonial. Rio de Janeiro: Nova Fronteira, 2000.

BRESCIA, R. M. O teatro efêmero na América Portuguesa: do teatro do Siglo de Oro ao teatro "ao gosto português". Nuevo Mundo Mundos Nuevos [On-line], Paris, 2010. Disponível em: <https://goo.gl/KSBMec>. Acesso em: 19 jun. 2017.

CAMPOS, A. A. Introdução ao barroco mineiro. Belo Horizonte: Crisálida, 2006.

FERNANDES, F. A integração do negro na sociedade de classes. São Paulo: Ática, 1978.

Significado do protesto negro. São Paulo: Cortez, 1989.

LANGE, C. História da música nas irmandades de Vila Rica: Freguesia de Nossa Senhora do Pilar do Ouro Preto. v. 1. Belo Horizonte: Publicações do Arquivo Público Mineiro, 1979.

A música barroca. In: FAUSTO, B.; HOLLANDA, S. B. (org.). História geral da civilização brasileira: administração, economia, sociedade. São Paulo: Difel, 1982

LARA, S. H. Fragmentos setecentistas: Escravidão, cultura e poder na América portuguesa. São Paulo: Companhia das Letras, 2007.

MACHADO, S. F. Triunfo Eucarístico, exemplar da cristandade lusitana em pública exaltação da fé na solene trasladação do Diviníssimo Sacramento da Igreja da Senhora do Rosário, para um novo templo da Senhora do Pilar em Vila Rica, corte da Capitania das Minas. In: AVILA, A. Resíduos Seiscentistas de Minas Gerais. Belo Horizonte: Universidade Federal de Minas Gerais, 1967b, p.129-283.

MONTEIRO, M. F. M. A dança na festa colonial. In: JANCSÓ, I.; KANTOR, I. (org.). Festa: cultura e sociabilidade na América portuguesa. São Paulo: Hucitec; EDUSP, 2001, v. II.

RIBEIRO, S. S. Summula Triumfal da nova e grande celebridade do glorioso e invicto martyr S. Gonçalo Garcia. Revista do Instituto Histórico e Geográfico Brasileiro, Rio de Janeiro, tomo 99, v. 153, 1926.

REVISTA DO ARQUIVO PÚBLICO MINEIRO. População da Província de Minas Geraes. Belo Horizonte: Imprensa Oficial de Minas Gerais, 1899. Disponível em: <https://goo.gl/hwQCyJ>. Acesso em: 19 jun. 2017.

SOUZA, L. M. Os desclassificados do ouro. Rio de Janeiro: Graal, 1986. 
Perfis brasileiros: Cláudio Manuel da Costa. São Paulo: Companhia das Letras, 2011.

SCHWARZ, R. As ideias fora do lugar. In: Cultura e política. São Paulo: Paz e Terra, 2009, p. 59-83.

TRINDADE, J. B. Arte colonial: Corporação e escravidão. In: ARAÚJO, E. (org.). A mão afrobrasileira: significado da contribuição artística e histórica. São Paulo: Tenenge, 1988.

Recebido em 09/02/2017

Aprovado em 02/06/2017

Publicado em 05/09/2017 